\title{
Pendidikan Seni Musik Tradisional Manggarai dan Pembentukan Kecakapan Psikomotorik Anak
}

\author{
Ambros Leonangung Edu ${ }^{1 *}$, Vitalis Tarsan ${ }^{2}$ \\ 1,2 STKIP Santu Paulus Ruteng, Flores - NTT
}

A R T I C L E I N F O

Article history:

Received 20 December 2018

Received in revised form 1 January 2019

Accepted 30 January 2019

Available online 27

February 2019

\section{Kata Kunci:}

pendidikan, seni musik tradisional, kecakapan psikomotorik

Keywords: education, traditional music arts, psychomotor skills.

\section{A B S T R A K}

Salah satu unsur budaya yang menjadi aset orang Manggarai adalah seni musik tradisional. Bagi generasi sekarang, aset budya ini cenderung termajinalisasi. Rasa cinta anak-anak Manggarai untuk bermain music tradisional makin memudar. Partisipasi anak-anak dalam membawakan music tradisional budaya Manggarai memprihatinkan. Anak-anak kurang mengenal birama musik tradisional Manggarai seperti takitu, kedendit, concong, mbata, ndundu ndake, mumere. Jika fenomena ini terus dibiarkan maka lambat laun generasi anak Manggarai kehilangan warisan kekayaan leluhur yang sangat berharga. Kegiatan Pengadian kepada Masyarakat PkM) ini dimaksudkan untuk menumbuhkembangkan dan melestarikan musik tradisional Manggarai. Selain itu, kegiatan PkM ini juga dimaksudkan untuk memperkuat dan meningkatkan kecakapan motorik anak SD Barang Cibal, melalui pelatihan birama music tradisional Manggarai: ndundu ndake, concong, kedindit, dan takitu. Kegiatan ini didasarkan pada analisis situasi problematik yang dihadapi mitra, anak-anak SD di Kampung Barang Cibal. Pendekatan yang dipakai dalam kegiatan ini adalah pendekatan edukasi melalui pelatihan. Metode yang dipakai adalah pelatihan yang dikemas dalam suasana fun learning. Tempat pelatihan dipusatkan di rumah gendang, rumah adat Manggarai, kampong Barang Cibal. Dalam proses pelaksanaannya, kegiatan pelatihan ini melewati beberapa tahap: persiapan; rancangan kegiatan PkM; dan pelaksanaan.

\section{A B S T R A C T}

One of the cultural elements that becomes the asset of Manggaraians is the art of traditional music. For the current generation, these culture assets tend to be marginalized. The love of Manggaraian childrens to play traditional music is increasingly fading. The participation of children in bringing traditional music to the Manggaraian culture is apprehensive. Children are not familiar with the traditional styles of Manggaraian music such as takitu, kedendit, concong, mbata, ndundu ndake, and mumere. If this phenomenon continues to be allowed, gradually the new generation of Manggaraians will lose its heritage of valuable ancestral wealth. This community service program is intended to foster and preserve Manggaraian traditional music. In addition, this activities are also intended to strengthen and improve the children's motor skills in Barang Cibal village, through training on Manggaraian traditional music: ndundu ndake, concong, kedindit, and takitu. This activity was based on an analysis of the problematic situation faced by partners, elementary school children in Cibal Barang village. The approach used in this activity was an educational approach through training. The method used is training that is packaged in a fun learning atmosphere. The training center was centered on the custome house, Manggaraian traditional house, at Cibal Barang village. In the implementation process, the training activities go through several stages: preparation; draft community service program; and implementation.

Copyright () Universitas Pendidikan Ganesha. All rights reserved.

\footnotetext{
* Corresponding author.

E-mail addresses: ambros.leonangung@gmail.com (Ambros Leonangung Edu)
} 


\section{Pendahuluan}

Salah satu tugas lembaga pendidikan adalah melakukan transmisi budaya (Pidarta, 2007:171), baik budaya lokal maupun budaya nasional. Tugas ini sangat strategis oleh karena pendidikan sejatinya adalah mengabdi kepada kepentingan masyarakat (Widyawati, 2017:i). Tugas lembaga pendidikan sebagai bagian dari tugas pewarisan nilai-nilai kebudyaan adalah membentuk dan mengembangkan generasi baru menjadi orang-orang dewasa yang berbudaya.

Salah satu dari sekian unsur kebudyaan yang perlu diwariskan adalah kesenian tradisional. Kesenian tradisional merupakan identitas kultural masyarakat yang berfungsi secara sosial dan ritual. Kesenian tradisional dipercaya masyarakat pendukungmya tidak sekadar sebagai hiburan yang menciptakan kegembiraan, namun ia juga menjadi media yang mampu memfasilitasi doa dan harapan mereka (Irianto, 2017).

Seni musik tradisional merupakan salah satu unsur bawahan langsung yang membentuk isi kebudayaan satu kelompok masyarakat budaya tertentu yang perlu diwariskan melalui proses pendidikan. Dalam dokumen Kurikulum 2013, Kementerian Pendidikan dan Kebudayaan, (2012:3) menyatakan bahwa...melalui pendidikan akan terjadi proses pengembangan potensi peserta didik sehingga mereka mampu menjadi pewaris dan pengembang budaya bangsa. Melalui pendidikan berbagai nilai dan keunggulan budaya di masa lampau diperkenalkan, dikaji, dan dikembangkan menjadi budaya dirinya, masyarakat, dan bangsa yang sesuai dengan zaman dimana peserta didik tersebut hidup dan mengembangkan diri...

Kesenian tradisional merupakan salah aset budaya yang perlu dipelihara dan diwariskan kepada generasi muda, terutama anak-anak usia sekolah. Sekolah sebagai institusi terdepan dalam pewarisan budaya perlu mempersiapkan anak didik untuk sanggup berkompetisi di era global dengan tetap berakar kuat pada moralitas yang dipelajari dari konteks kultural lokal. Oleh karena itu, semua pihak: orang tua, pendidik, lembaga swadaya masyarakat, dan tokoh-tokoh adat harus terlibat dalam upaya pembentukan generasi millenial yang tetap berakar pada budaya dan kearifan lokal. Mengapa demikian karena tanpa memperkuat pendidikan budaya dan kearifan local mereka akan menjadi generasi yang tercabut dari akar budaya mereka. Dampak lanjutannya adalah mereka akan menjadi generasi yang tidak memiliki identitas.

Selain itu, fenomena yang terjadi saat ini, adalah eksistensi budaya dan kearifan local cenderung termajinalisasi karena generasi penerus budaya bangsa lebih cenderung beralih ke budaya modern yang selalu up date, fun, dan sensual. Pengaruh negative globaliasasi dan perkembanagn teknologi komunikasi saat ini juga memperlihatkan bahwa generasi millennial cenderung mengabaikan warisan budaya local, antara lain kesenian tradisional. Saat ini mungkin tidak banyak dari kita yang mengetahui apa itu musik tradisional. Karena di jaman yang semakin modern ini banyak orang yang mulai meninggalkan musik tradisional. Ada juga sebagian orang yang tidak mengenalnya, bahkan tidak mau mengenalnya sama sekali dengan banyak alasan.

Musik tradisional adalah musik yang bersifat khas dan mencerminkan kebudayaan suatu etnis atau masyarakat tertentu. Musik tradisional menjadi suatu cetusan perasaan atau ekspresi melalui nada atau suara dari alat musik sehingga mengandung lagu atau irama yang diwariskan secara turun temurun dari satu generasi ke generasi selanjutnya. Musik tradisional, baik itu kumpulan komposisi, idiom, struktur dan instrumentasinya serta gaya maupun elemen-elemen dasar komposisinya, seperti ritme, modus, melodi atau tangga nada, tidak diambil dari sistem musikal yang berasal dari luar kebudayaan suatu masyarakat pemilik musik yang dimaksud tersebut.

Seni musik tradisional di Nusantara ini amat beragama dan tetap eksis pada masyarakat yang masih memelihara warisan-warisan leluhurnya. Musik tradisional sebenarnya tidak bersifat stagnan atau tidak berubah, melainkan telah mengalami evolusi dalam waktu yang panjang dan mencapai bentuknya yang mapan. Untuk memahami musik tradisional, maka dibutuhkan ketajaman rasa, pengetahuan luas, dan pengalaman yang memadai (Astono, 2008). Orang Flores misalnya, hanya dapat memahami cita rasa musikal Jawa karena sering melihat dari dekat pertunjukan musik orang-orang Jawa.

Saat ini, daya tarik musik tradisional cenderung ditinggal oleh musik-musik pop modern. Generasi baru tampaknya makin melekat pada lagu dan tarian modern ketimbang atraksi-atraksi tradisional. Demam K-pop dan boy band yang menjamur belakang ini menjadi ikon anak-anak zaman sekarang. Macho adalah ikon mereka ketika koleksi lagu dalam album pribadi beraroma Korea-koreaan atau kebaratbaratan. Namun, siapa bisa menyangka konten musik-musik pop itu terselubung eksotisme dan sensualisme murahan yang menggelora atas nama seni. Gaya hidup parlente, cinta semu, putus asa, dan beragam pesona erotisme seksual yang dominan mengisi sayir-syair lagu dan tarian-tarian modern mengekspresikan citra seksualitas artifisial siap melahap hati nan lugu para penggemarnya, anak-anak muda. Promosi yang ambisius ini sebenarnya berkerudung semangat kapitalisme yang mencari untung di 
balik ideologi-ideologi yang diciptakan. Generasi baru enggan untuk berpaling pada pola-pola tradisional yang cenderung stagnan dan stabil, tetapi mengarahkan mata pada kesenangan saat ini.

Di Kampung Barang, Kecamatan Cibal, Kabupaten Manggarai; berdasarkan pantauan awal tim pengabdian kepada masyarakat memperlihatkan bahwa; rasa cinta dan kemampuan anak-anak untuk bermain musik tradisional budaya Manggarai makin memudar. Partisipasi anak-anak dalam ritus-ritus komunal budaya Manggarai sebagai medan bertumbuhnya estetika lokal dan moralitas yang terwarisi dari generasi tua, memprihatinkan. Anak-anak kurang mengenal birama musik tradisional budaya Manggarai seperti takitu, kedendik, concong, mbata, ndundu ndake, mumere. Mereka lebih mengenal lagulagu popuper dan tarian-tarian yang mudah mereka dapat dari televisi atau internet. Dampaknya, warisan musik tradisional budaya Manggarai sendiri semakin kurang dikenal dan bahkan diabaikan sama sekali.

Oleh karena itu, seturut paradigma K-13, pembelajaran ideal bersumber dari fenomena sosial, alam, dan budaya setempat sebagai locus dan momen bagi kontekstualitas dan aktualitas pembelajaran; maka perlu ada upaya dari berbagai pihak: orang tua, pendidik, lembaga swadaya masyarakat, dan tokoh-tokoh adat agar nilai dan warisan budaya Manggarai tersebut tidak dibaikan begitu saja. Sebaliknya, warisan budaya Manggarai, dalam hal ini adalah kemampuan/kecapakan bermain alat music tradisional, harus dilestarikan melalui pendidikan dan/atau pelatihan. Maka sekolah sebagai lembaga pendidikan yang bertugas melakukan transmisi budaya harus turut bertanggung jawab atas persoalan tersebut. Faktanya bahwa sekolah-sekolah di Manggarai belum memiliki konsep yang matang bagaimana agar warisan budaya Manggarai tetap lestari.

Berangkat dari fenomena tersebut, maka tim tergerak untuk merancang kegiatan Pengabdian kepada Masyarakat (PKM). Kegiatan PkM ini diharapkan selain untuk menjawabi kebutuhan di lapangan juga diharapkan; 1) dapat memperkuat dan meningkatkan pemahaman anak-anak SD di Kampung Barang Cibal tentang macam-macam seni musik tradisional Manggarai; (2) dapat memperkuat dan meningkatkan pembentukan keterampilan bermain alat-alat musik tradisional; (3) serta dapat memperkuat kecakapan psikomotor anak-anak SD di Kampung Barang Cibal

Maka pendekatan yang dipakai agar persoalan kelompok sasaran dapat diatasi, maka tim merancang kegiatan edukasi anak-anak SD di Kampung Barang Cibal, melalui pelatihan secara intensif. Kegiatan pelatihan dibantu oleh fasilitator berkompeten dalam memainkan musik tradisional Manggarai seperti bapak-bapak dan ibu-ibu yang berpengalaman dalam takitu, kedendik, concong, mbata, ndundu ndake, dan mumere

\section{Metode}

Untuk memecahkan situasi problematik yang dihadapi mitra sekaligus untuk memperkuat kecakapan psikomotor anak-anak SD di Kampung Barang Cibal dalam memainkan alat musik tradisional Manggarai, maka ditawarkan pendekatan edukasi melalui pelatihan. Metode yang dipakai adalah pelatihan yang dikemas dalam suasana pembelajaran yang menyenangkan (fun learning). Sasaran pelatihan kami adalah anak-anak SD di Kampung Barang berjumlah 28 orang. Pelatihan diawali dengan membangun asumsi awal bahwa anak-anak SD di tempat tersebut perlu dibekali dengan pendidikan seni musik tradisional di tengah ancaman kehilangan rasa cinta generasi baru terhadap karya-karya artistik tradisional. Untuk itu, kami mengajarkan anak-anak cara bermain birama-birama musik tradisional yang dilatih di rumah adat (mbaru gendang) bukan oleh guru dan kepala sekolah saja melainkan juga para tua adat, orang-orang tua, dan fasilitator terlatih yang kami pilih.

Pelatihan birama musik tradisional Manggarai ini merupakan bentuk pengabdian kepada masyarakat kepada kelompok sasaran yaitu anak-anak sekolah dasar di kampung Barang, Kabupaten Manggarai, Flores. Dalam proses pelaksanaannya, kegiatan pelatihan ini melewati beberapa tahap: pertama, persiapan; kedua, rancangan kegiatan PkM; dan yang ketiga adalah pelaksanaan. Adapun kegiatan yang dilakukan pada masing-masing tahap adalah sebagai berikut:

1) Tahap Persiapan.

Pada tahap ini tim PkM memilih SD Barang, Kampung Barang, Kecamatan Cibal, Kabupaten Manggarai sebagai mitra tempat dimana tim melakukan PkM. Sebelumnya, tim melakukan diskusi dengan tua-tua adat dan guru di Kampung Barang, mengenai kemampuan anak-anak SD dalam memainkan alat musik tradisional Manggarai. Hasil diskusi menunjukkan bahwa rasa cinta dan kemampuan anak-anak SD Barang untuk bermain musik tradisional budaya Manggarai, seperti: takitu, kedendit, concong, mbata, ndundu ndake, mumere makin memudar. Selain itu, partisipasi mereka dalam ritus-ritus budaya Manggarai memprihatinkan. Mereka lebih mengenal musik modern dari pada mengenal warisan budaya Manggarai sendiri.

Selanjutnya, tim melakukan diskusi secara bersama mengenai permasalahan yang ditemukan di lapangan.Tim akhirnya sepakat untuk melakukan kegiatan pengabdian masyarakat untuk memberikan 
pemecahan praktis atas situasi problematik yang dihadapi anak-anak SD Barang, Kabupaten Manggarai. Situasi yang dihadapi adalah mulainya kehilangan keterampilan memukul alat-alat musik tradisional. Hal ini mengancam proses pendidikan atau pewarisan nilai-nilai tradisional kepada generasi muda.

2) Penyusun Rancangan PkM

Setelah tim berdiskusi serta memastikan pemecahan praktis atas permasalahan yang ditemukan, selanjutnya tim membuat rancangan PkM. Ada beberapa kegiatan yang dilakukan pada tahap ini, antara lain; 1) melakukan studi pustaka terfokus pada dua poin penting: seni musik tradisional Manggarai dan kecakapan psikomotorik anak, dalam hal ini adalah kemampuan memainkan takitu, kedendik, concong, mbata, ndundu ndake, mumere; 2) melakukan koordinasi dengan sekolah, para tua adat, orang tua, dan pemilik rumah gendang/rumah adat Manggarai; 3) memilih tutor yang berpengalaman dalam memainkan alat musik tradisional Manggarai; 4) menentukan jenis musik tradisional yang akan dilatih; 5) menentukan jadwal pelatihan PkM; 6) menyiapkan alat musik: gong dan gendang, serta menyiapkan instrument: kamera, alat tulis, balpoin, dan lain-lain.

3) Tahap Pelaksanaan.

Pada tahap pelaksananaan, tim melakukan kegiatan, yakni pratindakan, tindakan, monitoring dan evaluasi. Pada tahap pratindakan/sosialisasi, tim dibantu fasilitator memberikan pengenalan birama/bunyi: ndundu dake, takitu, kedendit, concong, mbata, dan mumere. Selanjutnya tim mengambil data berupa tes kemampuan awal siswa. Pada tahap tindakan/perlakuan, tim dibantu fasilitator memberikan pelatihan tentang keempat birama musik tradisional Manggarai. Setelah itu tim memastikan kemampuan/kecakapan psikomotor siswa dalam memainkan alat music tersebut, dengan melakukan monitoring pada saat proses memainkan alat musik berlangsung. Kemudian, tim melakukan evaluasi/refleksi, untuk melihat kekuatan/kelebihan/kepandaian para siswa dalam memainkan alat music, serta menemukan kekurangan yang ada dalam memainkan alat music tersebut untuk melakukan perbaikan pada tahap selanjutnya

\section{Hasil dan pembahasan}

Pelaksanaan pelatihan seni musik tradisional Manggarai dalam rangka meningkatkan kecakapan psikomotorik anak SD Barang Cibal, dilaksanakan di Kampung Barang, Kecamatan Cibal, Kabupaten Manggarai. Pada awal/pratindakan, tim PkM dibantu oleh fasilitator memperkenalkan macam-macam seni musik tradisional Manggarai. Perkenalan macam-macam seni musik tradisional Manggarai ini dilakukan selain dengan ceramah juga dengan pendekatan simulasi dan pelatihan.

Simulasi dan pelatihan difokuskan pada empat birama: ndundu ndake, concong, kedindit dan taketu. Semua empat birama ini menggunakan alat musik gong dan gendang yang biasa dimainkan saat upacara adat seperti congko lokap, penti, roko molas poco, dan lain-lain. Alat musik gendang itu sendiri terbuat dari berbagai macam kulit hewan seperti kerbau, kambing dan sapi. Kulit hewan yang paling sering digunakan adalah kulit kambing jantan karena lebih awet, gaung serta tahan terhadap pukulan.

Meskipun gendang selalu dipajang di rumah adat tetapi pemakaiannya hanya diperbolehkan saat-saat upacara resmi. Sementara itu, alat musik gong (nggong) terbuat dari drum supaya menghasilkan bunyi yang gaung. Kayu pukul gong diambil dari kayu kapuk (haju kawu), bagian depan area pukulan dilapisi kulit kambing (luit mbe) khususnya kulit alat kelamin kambing jantan (luit telo de mbe laki) (Rhinji, 2016).

Kedua alat tersebut (gendang dan gong) dipakai untuk dipermainkan sehingga menghasilkan birama (jenis pukulan) yang disebut ndundu ndake, concong, kedindit dan taketu. Ada dua jenis pukulan yakni pukulan halus dan keras-cepat. Jenis pukulan pelan adalah taketu, deras adalah kedendit yang menggunakan dua gendang dan dipakai untuk mengiring tari-tarian adat. Ndundundake adalah jenis bunyi cepat. Dari empat birama tersebut, ndundu ndake dan concong adalah birama paling dasar yang harus dikuasai dengan mahir sebelum mengenal birama kedindit dan taketu. Dua birama terakhir merupakan variasi setelah seseorang bermain ndundu ndake dan concongdengan mahir.

Empat birama ini merupakan birama dominan dalam musik tradisional Manggarai sebagai birama pengiring tari dan lagu daerah Manggarai untuk setiap kegiatan budaya, antara lain acara penti, congko lokap, dan lain-lain.

Untuk membentuk kemampuan serta meningkatkan kecakapan psikomotorik anak, tim PkM meminta tutor/fasilitator untuk melatih anak-anak SD di Kampung Barang Cibal. Para tutor diambil dari warga yang berkompeten dalam pengetahuan dan keterampilan memainkan alat musik tradisional. Keempat birama di atas diperkenalkan kepada anak-anak SD di kampung Barang. Berikut pelaksanaan kegiatan yang telah dilakukan: 
Tabel 1. Pelaksanaan Kegiatan

\begin{tabular}{lll}
\hline No & Waktu & Kegiatan \\
\hline 1 & Sabtu, 8 April 2017 & Pengenalan bunyi/birama \\
2 & Sabtu, 6 Mei 2017 & pengenalan ndundu ndake dan concong \\
3 & Sabtu, 13 Mei 2017 & latihan lanjutan \\
4 & Sabtu, 20 Mei 2017 & pengenalan kedindit dan taketu \\
5 & Sabtu, 10 Juni 2017 & latihan lanjutan \\
6 & Sabtu, 17 Juni 2017 & Evaluasi (simulasi) birama ndundu ndake dan concong \\
7 & Sabtu, 24 Juni 2017 & Evaluasi (simulasi) birama kedindit dan taketu \\
8 & Sabtu, 1 Juli 2017 & Simulasi umum empat birama \\
\hline
\end{tabular}

Setelah tindakan dilakukan sebanyak 8 kali terhadap 28 orang anak. Hasil penelitian menunjukkan adanya peningkatan dari hasil tes pratindakan, tes I, dan tes II.

Tabel 2. Hasil Pre-test

\begin{tabular}{lllll}
\hline \multicolumn{2}{c}{ Jumlah Anak } & \multicolumn{3}{c}{ Birama } \\
\hline 28 & Ndundu Ndake & Concong & Kedindit & Taketu \\
& $33(29,5 \%)$ & $37(33,03 \%)$ & $30(26,79 \%)$ & $27(24,11 \%)$ \\
\hline
\end{tabular}

Kondisi awal memperlihatkan bahwa kondisi anak-anak SD Barang kurang mahir dalam bermain birama musik tradisional. Mereka dapat memegang alat-alat musik dan pernah mendengarkan lantunan birama yang diperdengarkan pada acara-acara adat, namun mereka tidak dapat memperagakannya. Gambaran perkembangan awal dapat dilihat pada grafik berikut.

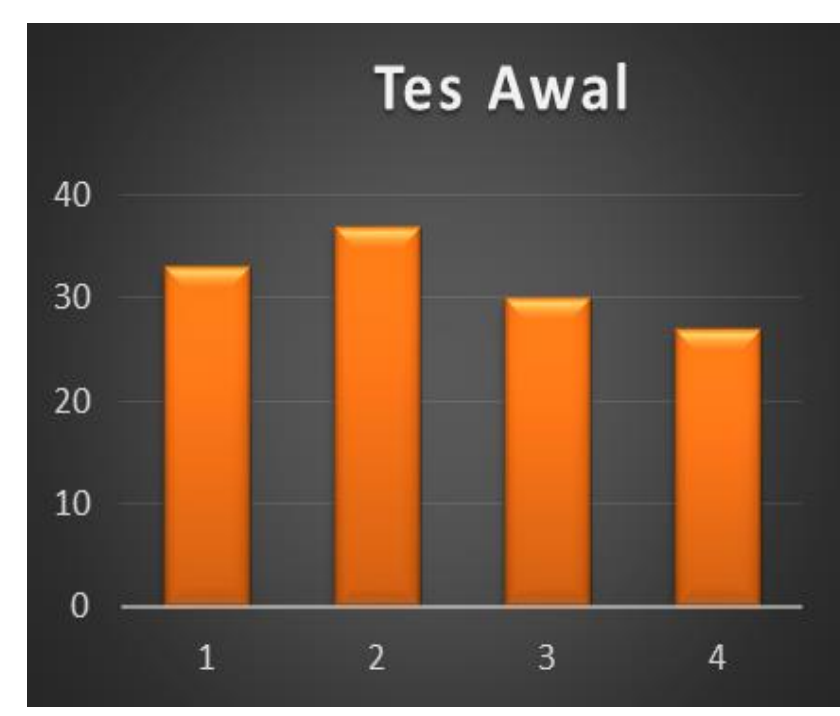

Gambar 1. Gambaran Perkembangan Awal

Selanjutnya peneliti melakukan tindakan. Tindakan yang dimaksudkan adalah memberikan pelatihan-pelatihan tentang keempat birama musik tradisional yang dilatih oleh sejumlah tenaga yang sudah disiapkan tim. Setelah lima kali diberi pelatihan, perkembangan kecakapan motorik bermain musik anak-anak SD Barang dilihat dan dinilai. Hasilnya ternyata lebih baik dan mengalami perubahan signifikan. Perubahan tersebut dapat dilihat pada tabel dan grafik berikut. 


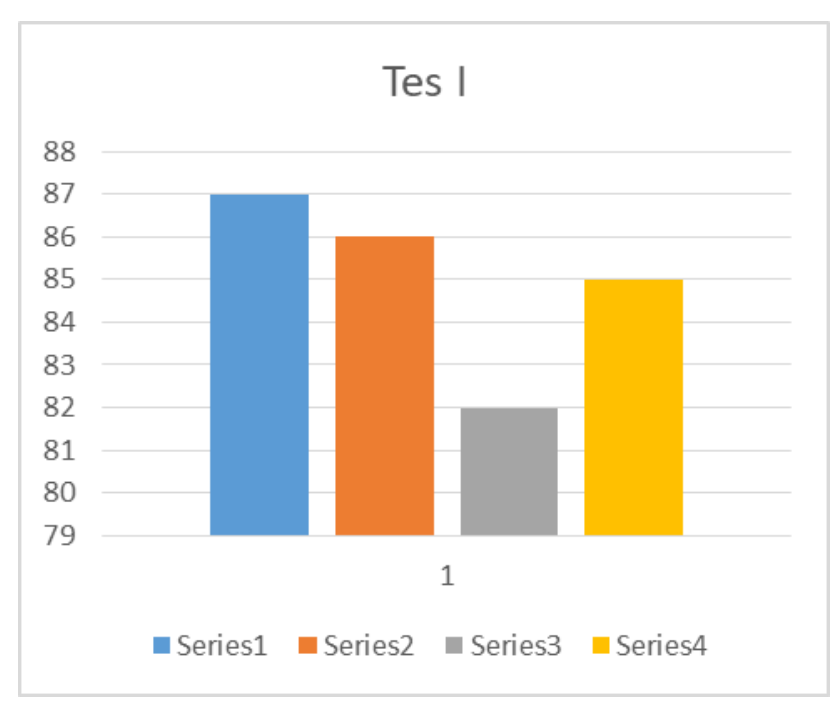

Gambar 2. Hasil Tes I

Pada bagian terakhir, tim dan para pelatih terus memantau perkembangan psikomotorik anakanak. Setelah melihat kekurangan pada evaluasi sebelum, tim bersama para pelatih memberikan pelatihan kontinu dan intensif, baik terencana sebagaimana sudah dijadwal maupun melalui latihan-latihan kelompok di antara anak-anak sendiri supaya mereka lebih fasih dan dapat dilihat kemajuannya pada saat presentasi pertemuan berikut. Tindakan yang dilakukan terhadap anak-anak dapat memperbaiki kekurangan. Hasil perubahan dapat dilihat pada Tabel 3 dan grafik berikut.

Tabel 3. Hasil Tes II

\begin{tabular}{|c|c|c|c|c|}
\hline \multirow[t]{2}{*}{ Jumlah Anak } & \multicolumn{4}{|c|}{ Birama } \\
\hline & $\begin{array}{l}\text { Ndundu Ndake } \\
87(77,68 \%)\end{array}$ & $\begin{array}{l}\text { Concong } \\
86(76,79 \%)\end{array}$ & $\begin{array}{l}\text { Kedindik } \\
82(73,21 \%)\end{array}$ & $\begin{array}{l}\text { Taketu } \\
85(75,89 \%)\end{array}$ \\
\hline
\end{tabular}

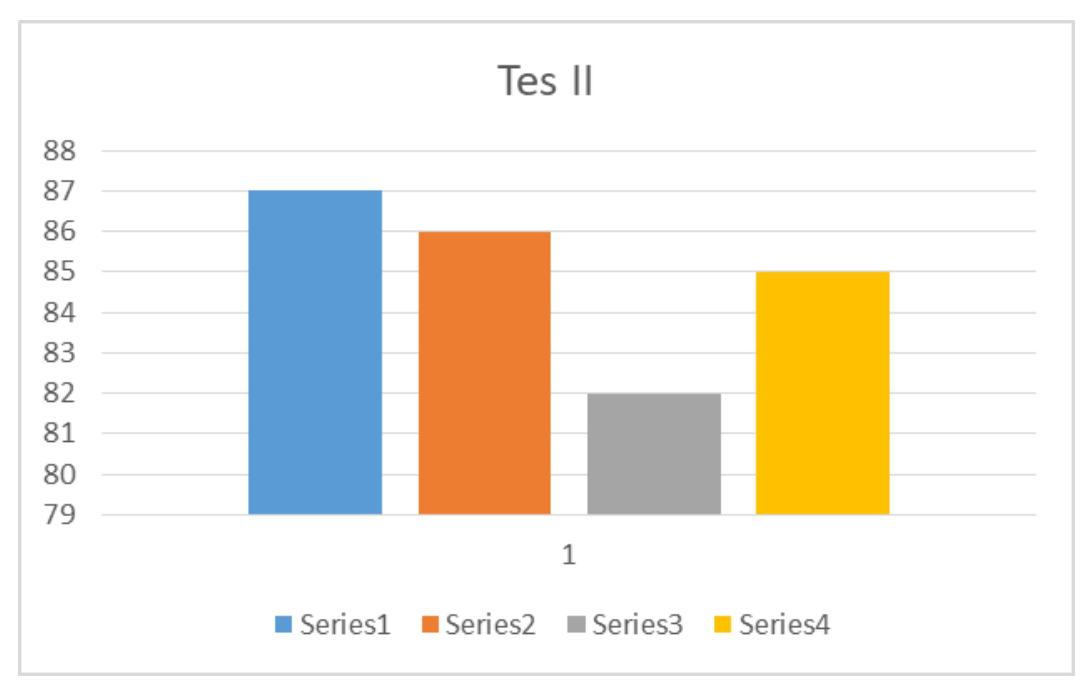

Gambar 3. Hasil Tes II

Kebudayaan dan masyarakat merupakan satu kesatuan yang tidak dapat dipisahkan. Tidak ada masyarakat tanpa kebudayaan, dan tidak ada kebudayaan tanpa kehadiran masyarakat. Orang-orang Manggarai pun demikian, mereka memiliki kebudayaan yang menyatu erat dengan kehidupan mereka. Majid (2015:7) menegaskan bahwa manusia membutuhkan seni untuk keperluan hidupnya, sedangkan seni membutuhkan manusia sebagai pendukungnya. Sebagai pendukungnya, diharapkan manusia dapat 
melestarikan dan mengembangkan melalui karya-karya baru yang disesuaikan dengan situasi dan kondisi zaman. Salah satu unsur kebudayaan yang melekat erat dengan jiwa orang Manggarai adalah kesenian. Kesenian adalah bagian yang indah dan halus dari suatu kebudayaan yang merupakan produk masyarakat yang berfungsi sebagai media ekspresi perasaan masyarakat tersebut. Kesenian tentu bukan hanya sebagai media ekspresi saja tetapi lebih dari itu yakni membangun dan melestarikan nilai-nilai hidup bermasyarakat.

Unsur seni yang digali dalam PkM ini adalah seni musik tradisional, dalam budaya masyarakat Manggarai. Seni musik merupakan cetusan perasaan atau ekspresi melalui nada atau suara dari alat musik sehingga mengandung lagu atau irama yang diwariskan secara turun temurun dari satu generasi ke generasi berikutnya. Menurut Purba (2007:2), musik tradisional tidak berarti bahwa suatu musik dan beragam unsur di dalamnya bersifat kolot, kuno atau ketinggalan zaman. Tetapi musik tradisional adalah musik yang bersifat khas dan mencerminkan kebudayaan suatu etnis atau masyarakat. Musik tradisional, baik itu kumpulan komposisi, idiom, struktur dan instrumentasinya serta gaya maupun elemen-elemen dasar komposisinya, seperti ritme, modus, melodi atau tangga nada, tidak diambil dari sistem musikal yang berasal dari luar kebudayaan suatu masyarakat pemilik musik yang dimaksud tersebut.

Kesenian tradisional, merupakan salah satu unsur di dalam kebudayaan yang tidak bisa terlepas dari kehidupan manusia. Kesenian tradisional adalah bentuk seni yang berasal dan tumbuh di tengah masyarakat beserta pendukungnya (Majid, 2015:6) Seni musik tradisional adalah musik yang berakar pada tradisi masyarakat tertentu, maka keberlangsungannya dalam konteks saat ini yaitu upaya pewarisan secara turun temurun masyarakat sebelumnya.

Demikian juga bagi orang Manggarai, jiwa seni diungkapkan antara lain, dalam memainkan alat music tradisional, yakni gong dan gendang. Kemampuan memainkan alat musik tersebut diwariskan secara turun temurun tanpa melalui pendidikan khusus, melainkan dengan melihat dan mencobanya sendiri. Tetapi karena pengaruh globalisasi kemampuan anak-anak Manggarai dalam memainkan alat music tersebut (gong dan gendang) makin pudar bahkan banyak anak usia sekolah yang cenderung abaikan untuk mempelajarinya. Sehingga banyak anak usia sekolah yang tidak tahu bagaimana memainkan alat music tersebut.

Dari survei yang dilakukan terhadap 20 orang mahasiswa multietnik asal Manggarai, Riung, Ende, Lembata, Adonara dan Belu menunjukkan bahwa dari 20 responden, 90\% berminat untuk mempelajari gong gendang, terdapat $15 \%$ yang mengetahui instrumen gong gendang dan irama pukulan gong gendang di daerahnya, dan $85 \%$ responden yang tidak tahu tentang dua hal di atas. Sedangkan dari segi kemampuan terdapat $15 \%$ yang cukup mampu memainkan gong gendang khas daerah, 55\% yang menjawab sedikit bisa memainkan salah satunya, dan $30 \%$ di antaranya menjawab tidak tau dan belum pernah mencoba (http://repository.unwira.ac.id/ 1905/2/BAB\%20I.pdf).

Tingginya persentase kaum muda yang tidak mampu memainkan alat music tradisional, gong dan gendang dalam konteks budaya Manggarai, menjadi indikasi kuat bahwa terdapat fenomena bergesernya kecintaan anak-anak usia sekolah, dalam masyarakat adat Manggarai, terhadap musik tradisional Manggarai. Hal ini senada dengan apa yang dikemukakan oleh Afriandi dan Erson (2009) seperti dikutip Zaenal, dkk (2016:68) yang menyatakan bahwa saat ini minat generasi muda untuk mempelajari budaya tradisional khususnya seni tari tradisional masih sangat rendah. Apabila permasalahan ini tidak segera diatasi maka bukan tidak mungkin bangsa Indonesia akan kehilangan jati dirinya di masa datang.

Hemat kami, problem ini perlu diatasi, antara lain melalui edukasi yakni kegiatan pelatihan. Fokus kegiatan pelatihan musik tradisional Manggarai dalam kegiatan PkM ini adalah kemampuan memainkan alat music tradisional gong dan gendan, terutama empat birama: takitu, kedendik, concong, mbata, ndundu ndake, mumere. Kelompok sasaran pelatihan adalah anak-anak SD Barang kelas 1-VI. Mengapa anak-anak SD? Karena selama ini yang memainkan music gong dan gendang dalam setiap acara seremonial adat adalah banyak dilakoni oleh para pelaku yang sudah tua, terutama bapak-bapak dan ibuibu. Jika tidak disosialisasikan kepada generasi muda, anak-anak SD, dikhawatirkan warisan kemampuan memainkan alat musik tersebut tidak dikenal oleh generasi selanjutnya di masa yang akan datang.

Selain itu, alasan mengapa pelatihan memainkan musik gong dan gendang dalam kegiatan PkM ini ditujukan kepada anak-anak SD? Juga dalam rangka meningkatkan kecapan motorik mereka. Penguatan dan peningkatan kecackapan motorik sangat penting dalam rangka menunjang pertumbuhan dan perkembangan pribadi, fisik anak-anak SD.

Berkaitan dengan perkembangan fisik Kuhlen dan Thompson, sebagaimana dikutip Hasanah (2016:720) mengemukakan bahwa perkembangan fisik individu meliputi empat aspek yaitu: (1) sistem syaraf, yang sangat mempengaruhi perkembangan kecerdasan dan emosi; (2) otot-otot, yang mempengaruhi perkembangan kekuatan dan kemampuan motorik; (3) kelenjar endokrin, yang menyebabkan munculnya pola-pola tingkah laku baru, seperti pada usia remaja berkembang perasaan 
senang untuk aktif dalam suatu kegiatan, yang sebagian anggotanya terdiri atas lawanjenis; dan (4) struktur fisik/tubuh, yang meliputi tinggi, berat dan proporsi.

Pelatihan ini adalah pembelajaran yang bersumber dari budaya Manggarai sebagai locus dan momen bagi kontekstualitas dan aktualitas pembelajaran. Suyadi (2013: 40-41), sebagaimana dikutip Aghnaita (2017:220) menegaskan bahwa pembelajaran harus mampu mengembangkan kecakapan hidup anak dari berbagai aspek secara menyeluruh (the whole child). Berbagai kecakapan dilatihkan agar anak kelak menjadi manusia seutuhnya. Bagian dari diri anak yang dikembangkan meliputi fisik-motorik, intelektual, moral, sosial, emosi, kreativitas, dan bahasa. Tujuannya adalah agar kelak anak berkembang menjadi manusia yang utuh dan memiliki kepribadian atau akhlak mulia, cerdas dan terampil, mampu bekerja sama dengan orang lain, mampu hidup bermasyarakat, berbangsa, dan bernegara

Seturut paradigma K-13, pembelajaran ideal bersumber dari fenomena sosial, alam, dan budaya setempat sebagai locus dan momen bagi kontekstualitas dan aktualitas pembelajaran. Tidak seperti kurikulum sebelum yang mencabut anak didik dari local genius, K-13 justeru mempersiapkan anak didik untuk sanggup berkompetisi di era global namun berakar kuat pada moralitas yang dipelajari dari konteks kultural lokal. Dalam K-13 juga ditegaskan bahwa praksis pembelajaran yang diharapkan tidak lagi berorientasi materi semata melainkan pada kecakapan lain yakni afektif dan psikomotorik. Dengan perkataan lain, program pengembangan keterampilan motorik merupakan tak terpisahkan dalam pendidikan menurut paradigma K-13.

Pada dasarnya, perkembangan motorik sejalan dengn kematangan saraf dan otot anak. Sehingga, setiap gerakan sesederhana apapun, adalah merupakan hasil pola interaksi yang kompleks dari berbagai bagian dan system dalam tubuh yang dikontrol oleh otak. Keterampilan motorik adalah gerakan-gerakan tubuh atau bagian-bagian tubuh yang disengaja, otomatis, cepat dan akurat. Gerakan-gerakan ini merupakan rangkaian koordinasi dari beratus-ratus otot yang rumit. Ketrampilan motorik ini dapat dikelompokkan menurut ukuran otot-otot dan bagian-bagian badan yang terkait, yaitu keterampilan motorik kasar (gross motor skill) dan keterampilan motorik halus (fine motor skill) (Hasanah (2016:721).

Terminologi "kecakapan psikomotorik" diperkenalkan oleh sejumlah pakar pendidikan, seperti Mager (1962), Bloom (1963), dan Gronlund (1970). Benjamin Bloom misalnya menggunakan tiga dimensi untuk menakar kualitas pendidikan, yakni kognitif, afektif, dan psikomotorik. Untuk lebih jelas, berikut indikator-indikator kecakapan psikomotorik (Harsanto, 2011).

Tabel 4. Dimesi Benjamin Bloon

Tingkat

1. Gerakan refleks

2. Gerakan kemampuan fisik
Arti

\section{Deskripsi}

a. Gerakan refleks adalah basis semua perilaku gerak

b. Responsif atas stimulus tanpa sadar misalnya melompat, merunduk, berjalan, menggerakkan leher dan kepala, menggenggam, serta memegang

c. Mengamati dengan saksama

d. Menulis alfabet

e. Mengulangi gerakan tarian

Arti

a. Gerakan yang lebih efisien

b. Lebih matang karena proses belajar. Contohnya: pengembangan dalam proses pembelajaran, yaitu:

a. Menggerakan otot selama kurun waktu tertentu

b. Berlari

c. Menangkat beban, menarik, mendorong, memperkuat tangan dengan berbagai kegiatan

d. Menari

e. Melakukan senam

f. Melakukan gerakan pesenam, pemain bola, dsb. 
3. Gerakan terampil

4. Gerakan indah dan kreatif
Arti

a. Dapat mengontrol berbagai tingkat gerak

b. Terampil, tangkas, dan cekatan dalam melakukan gerakan yang sulit dan rumit Contoh pengembangan dalam proses pembelajaran, yaitu:

a. Melakukan gerakan dengan terampil

b. Menari dan berdansa

c. Membuat kerajinan tangan

d. Memainkan alat musik

Arti

a. Mengkomunikasikan perasaan melalui gerakan

b. Gerakan estetik: gerakan-gerakan terampil yang efisien dan indah

c. Gerakan kreatif: gerakan-gerakan tingkat tertinggi untuk mengkomunikasikan peran

Sifat-sifat perkembangan fisik menurut Mursid, sebagaimana dikutip dikutip Hasanah (2016:720) dapat diamati adalah sebagai berikut:

1. Terjadi perkembangan otot-otot besar cukup cepat pada usia 2 tahun terakhir masa anak kecil. Hal ini memungkinkan anak melakukan berbagai gerakan yang lebih leluasa yang kemudian bisa dilakukannya bermacam-macam keterampilan gerak dasar. Beberapa macam gerak dasar meliputi: meloncat, berlari, melempar, menangkap, dan memukul berkembang secara bersamaan tetapi dengan irama perkembangan yang berlainan.

2. Dengan berkembangnya otot-otot besar, terjadi pulalah perkembangan kekuatan yang cukup cepat, baik pada anak laki-laki maupun perempuan.

3. Pertumbuhan kaki dan tangan secara proporsional lebih cepat disbanding pertumbuhan bagian tubuh yang lain,menghasilkan peningkatan daya ungkit yang lebih besar di dalam melakukan gerakan yang melibatkan tangan dan kaki.

4. Terjadi peningkatan koordinasi gerak dan keseimbangan tubuh yang cukup cepat.

Meningkatnya kemungkinan dan kesempatan melakukan berbagai macam aktivitas gerak fisik bisa merangsang perkembangan pengenalan konsep-konsep dasar objek, ruang, gaya, waktu dan sebab-akibat.

\section{Simpulan dan saran}

Musik tradisional Manggarai merupakan salah satu aset budaya suku bangsa yang perlu dilestarikan. Bentuk pelestarian yang dapat dibuat untuk tingkat local adalah memasukan pendidikan seni music tradisional Manggarai dalam kurikulum di sekolah atau dengan pendekatan edukasi melalui pelatihan. Hal ini sangat penting dibuat agar anak-anak Manggarai tidak kehilangan warisan budaya nenek moyangnya.

Kegiatan PkM yang dilaksanakan tim PkM di SD Barang, Kampung Barang, Cibal merupakan upaya untuk menumbuhkembangkan dan melestarikan musik tradisional Manggarai sehingga generasi anak Manggarai selanjutnya tidak kehilangan identitasnya, warisan kekayaan leluhur yang sangat berharga. Selain itu, kegiatan PkM ini juga dimaksudkan untuk memperkuat dan meningkatkan kecakapan motorik anak SD Barang Cibal, melalui pelatihan macam-macam birama music tradisional Manggarai: ndundu ndake, concong, kedindit, dan takitu.

\section{Daftar Rujukan}

Astono, Sigit, dkk. 2008. Seni Tari dan Seni Musik. Bandung: Yudhistira.

Aghnaita. 2017. "Perkembangan Fisik-Motorik Anak 4-5 Tahun Pada Permendikbud no. 137 Tahun 2014 (kajian konsep perkembangan anak)”, Jurnal Pendidikan Anak, Vol.3 No.2:219-234.

Djohan. 2006. Terapi Musik: Teori dan Aplikasi. Yogyakarta: Galangpress.

Harsanto, Radno. 2011. Paradigma Baru Pembelajaran Menuju Kecakapan Siswa. Yogyakarta: Kanisius. 
Hasim, Hernowo. 2016. "Flow" di Era Sosmed: Efek-Dahsyat Mengikat Makna. Bandung: PT Mizan Pustaka.

Hasanah, Uswatun. 2016. "Pengembangan Kemampuan Fisik Motorik Melalui Permainan Tradisional Bagi Anak Usia Dini”, Jurnal Pendidikan Anak, Volume 5, Edisi 1: 717-773

Irianto, Agus M. 2017. “Kesenian Tradisional Sebagai Sarana Strategi Kebudayaan di Tengah Determinasi Teknologi Komunikasi”, Jurnal NUSA, Vol. 12. No. 1: 90-100."

Jeratu, Damasus. “Kultur Manggarai”, Manuskrip. Ruteng, 2010.

Majid, Abdul. 2015. Eksistensi, Bentuk Penyajian Dan Fungsi Kesenian Tradisional Orek-Orek Di Kabupaten Rembang. Skripsi tidak diterbitkan. Semarang: Universitas Negeri Semarang.

Nggoro, Adi M. 2006. Budaya Manggarai Selayang Pandang. Ende: Nusa Indah.

Rhinji, Vian. 2016. "Mengenal Musik Tradisional Manggarai", dalam https://vianusjebarussrinji.wordpress.com/2015/12/11/ekspedisi-mengenal-musik-tradisionamanggarai/

Sutardi, Tedi. 2007. Antropologi: Mengungkap Keragaman Budaya. Bandung: PT Setia Purna Inves.

Pidarta, Made. 2007. Landasan Kependidikan: Stimulus Ilmu Pendidikan Bercorak Indonesia. Jakarta: Rineka Cipta.

Widhyatama, Sila. 2012. "Pola Imbal Gamelan Bali dalam Kelompok Musik Perkusi Cooperland di Kota Semarang," Jurnal Seni Musik. JSM I (1) (2012)

Widyawati, Fransiska, ed. Eksplorasi Budaya dan Masyarakat dalam Pendidikan. Ruteng:STKIP Santu Paulus Ruteng.

Zaenal, dkk., 2016. "Edukasi Sampyong untuk Menguatkan Eksistensi Kesenian Tradisional di Majalengka" Jurnal Agrokreatif Vol 2 (2): 67072. (http://repository.unwira.ac.id/1905/2/BAB\%20I.pdf, diakses 27 November 2018.

Wawancara: Anselmus Anta (59 tahun), Zakarias (63 tahun), Wihelmus Jebarus (58 tahun), Laurensius Pagar (48 tahun) 